\title{
A Study of Morphophysiological Descriptors of Cultivated Anthurium andraeanum Hort.
}

\author{
Winston Elibox and Pathmanathan Umaharan ${ }^{1}$ \\ Department of Life Sciences, Faculty of Science and Agriculture, The University \\ of the West Indies, St. Augustine Campus, College Road, St. Augustine, Republic \\ of Trinidad and Tobago
}

Additional index words. coefficient of variation, correlation, descriptors, frequency distribution, index of differentiation, showiness, principal component analysis

\begin{abstract}
Sixteen morphophysiological parameters of horticultural importance were investigated in 82 anthurium accessions grown in the Caribbean. The spathe colors included red, pink, white, green, orange, purple, coral, and brown and obake types with red, pink, and white spathe colors accounting for $63.4 \%$ of the accessions. There was wider variation in spadix color combinations than spathe color. There was wide variation for the cut flower and leaf parameters evaluated with productivity and peduncle length having the smallest and largest range, respectively. The frequency distributions were skewed to the right for spathe length, spathe width, spathe size, spadix length, spadix diameter, leaf width, leaf size, and productivity and was normal for leaf length, spadix angle, peduncle length, petiole length, and spathe showiness. Accessions with wider leaves had longer leaves and longer petioles; those with longer spathes had wider spathes; and those with longer peduncles had correspondingly longer petioles. Peduncle length also showed moderate, weak correlations with other leaf measurements and spathe parameters, respectively. Spadix diameter showed moderate correlations with leaf parameters. Spathe showiness showed moderate, weak correlations with spathe measurements and productivity, respectively. Principal component analysis of the 13 quantitative parameters showed that the first three principal components explained $75 \%$ of the variation in the accessions. Leaf length, leaf width, leaf size, petiole length, peduncle length, and spadix diameter; spathe length, spathe width, spathe size, and spathe showiness; and productivity loaded on the first, second, and third component, respectively. Hence, one leaf and one spathe size parameter, spathe showiness, petiole length, peduncle length, spadix length, spadix angle, spadix diameter, and productivity as well as spathe, spadix, peduncle, and petiole colors can be used as descriptors for anthurium. Based on these results and market information, an Anthurium ideotype adapted to the humid tropics is described.
\end{abstract}

Anthurium is a neotropical genus (Croat, 1988) belonging to the monocotyledonous family, Araceae, which includes more than 100 genera and $\approx 1500$ species (Higaki et al., 1994). Native species of anthurium occur from northern Mexico through Central America and the Caribbean to southern Brazil (Kamemoto and Kuehnle, 1996). Cultivated anthurium belongs to only two (Calomystrium and Porphyrochitonium) of the 18 sections outlined by Kamemoto and Kuehnle (1996). Interspecific hybridization between species of anthurium belonging to the section, Calomystrium, has resulted in an anthurium species complex referred to as Anthurium andraeanum Hort.

Received for publication 10 May 2012. Accepted for publication 26 June 2012.

This study was funded by the EUFORUM/ CARIFORUM under the Caribbean Agricultural Technology Fund (CARTF) program.

We thank the management and staff of Kairi Blooms Farm for providing the facilities for the research and Ms. Marilyn Goddard for her technical assistance.

${ }^{1}$ To whom reprint requests should be addressed; e-mail Pathmanathan.Umaharan@sta.uwi.edu.
Anthurium is cultivated primarily for its showy cut flowers and glossy leaves, which are exported or sold locally. The cut flower comprises a spadix with over 300 spirally arranged minute flowers subtended by a brightly colored modified leaf, the spathe (Croat, 1988). Anthurium cut flowers are generally classified as standard-colored, obake types, or patterned types (Kamemoto and Kuehnle, 1996). Standard types have a uniform color and may be red, pink, orange, coral, white, green, or purple. Obake types are bicolors with green at the lobes and another color at the center of the spathe. Other colors and patterns arise because of copigmentation (Kamemoto and Kuehnle, 1996) or because of regulatory patterning (stripes or splashes).

The important horticultural features of the cut flower are its color, size, texture, shape and showiness of the spathe, spadix length and carriage, straightness of the peduncle and peduncle length, overall symmetry of the cut flower, and productivity (Kamemoto and Kuehnle, 1996; Kamemoto et al., 1986).

Anthurium andraeanum Linden ex André was first introduced in the Caribbean in 1915 by Eugene André (Rapsey and Carr, 1968). With anthurium gaining popularity in the 1970s, many more accessions were introduced from The Netherlands (Dilbar, 1992). There are no standardized morphophysiological descriptors for anthurium available in the literature to characterize accessions of A. andraeanum Hort. or differentiate between them. Furthermore, the introduced accessions have not been systematically evaluated for horticultural performance and adaptability under local conditions. This information is critical for selecting parents for subsequent studies and for embarking on a breeding program.

The objective of the study was to determine useful morphophysiological descriptors for horticultural characterization of cultivated anthurium accessions as well as to identify a promising ideotype for breeding purposes.

\section{Materials and Methods}

Location. The experiment was conducted in a commercial farm, Kairi Blooms Ltd., situated in Arima, Trinidad and Tobago. The location experiences two seasons: a dry season (January to May) and a wet season (June to December). The average relative humidity, temperature, and light intensity are $83 \%$, $27.7^{\circ} \mathrm{C}$, and $57 \mu \mathrm{mol} \cdot \mathrm{m}^{-2} \cdot \mathrm{s}^{-1}$, respectively.

Anthurium accessions and cultural conditions. Eighty-two anthurium accessions were evaluated at full maturity, between the ages of 3 and 5 years. The accessions were grown under standard growing conditions in shade houses ( $75 \%$ shade) on beds $(22.9 \mathrm{~m} \times$ $1.2 \mathrm{~m}$ ) of pulverized coconut husk at a spacing of $45 \mathrm{~cm} \times 40 \mathrm{~cm}$. The plants were irrigated once daily for $15 \mathrm{~min}$ by overhead sprinkler irrigation in the dry season and as required in the wet season.

The beds were fertilized with either triple superphosphate (Chemos GmBH, Regenstauf, Germany) or $12 \mathrm{~N}-11 \mathrm{P}-13 \mathrm{~K}$ (Norsk Hydro Olje AB, NYBRO, Sweden) every month at a rate of $0.45 \mathrm{~kg}$ per bed. Urea (National Agro, Port of Spain, Trinidad) and diammonium phosphate (Brenntag, Dominican Republic) were applied as necessary at a rate of $0.23 \mathrm{~kg}$ per bed. The $\mathrm{pH}$ of the beds was maintained at 5.5 by regular liming (Limestone; TRINCARB, Port of Spain, Trinidad). Nematodes were controlled by application of Temik (Aldicarb, Shandong, China) every 6 months.

Phytosanitation was performed once a week and the infected materials and weeds were removed and burnt. Three-fourths ripe cut flowers were harvested on a daily basis from Monday to Friday between 0700 and 1100 HR.

Experimentation. The accessions were arranged in multiple beds within the shade houses. Ten guarded plants were randomly selected from the beds planted with a particular accession and evaluated for 16 leaf and cut-flower parameters. All linear measurements were done to $1 \mathrm{~mm}$ accuracy using a measuring tape (Knight $3.6 \mathrm{~m}$ tape, Taiwan), except for spadix diameter, which was measured with a pair of calipers (ENKAY Vernier Caliper 5-inch scale; Lo. 430-C ENKAY, Brooklyn, NY) halfway along its length. 
Spadix length was measured as the distance from the point of attachment of the inflorescence at the peduncle to the tip for $3 / 4$ ripe spadices (Dai and Paull, 1990). The length of the spathe was measured from the uppermost lobe border to the tip as described by Rosario (1981). The width of the spathe was measured as the edge-to-edge perpendicular distance directly behind the spadix (Dufour and Guerin, 2003; van Herk et al., 1998). Spathe size for each accession was calculated by multiplying spathe length by spathe width. Peduncle length was measured as the linear distance from the point of attachment of the spathe to the point of attachment of the stem (Elibox and Umaharan, 2008a).

The angle of the spadix relative to the spathe (spathe carriage) was measured with a protractor from the base of the spadix (Elibox and Umaharan, 2008a). The colors of the spathe, spadix, and peduncle were also recorded using a horticultural color chart (Wilson Color Ltd., U.K.).

Leaf parameters were measured using the second fully opened leaf. Leaf length was taken as the linear distance from the uppermost lobe border to the tip (Dai and Paull, 1990; Rosario, 1981). The width was measured as the edge-to-edge perpendicular distance from the point of attachment of the petiole to the lamina (Dufour and Guerin, 2003). Leaf size for each accession was calculated by multiplying leaf length by leaf width. The petiole length was a measure of the distance of the petiole at the point of attachment to the lamina and the point of attachment of the two stipules. Spathe showiness was calculated as the difference between the peduncle length and the petiole length for each accession.

Productivity was measured as the average number of cut flowers from 10 randomly selected guarded plants per accession over a period of 1 year. To easily identify a plant used in this study, a piece of flagging tape was tied around the petiole of the youngest leaf. Plants were tagged with a white plastic tag that was ticked every time a new cut flower appeared.

Data analysis. Frequency distributions were drawn for each of the 13 quantitative parameters for the 82 accessions of $A$. andraeanum Hort. and the Shapiro-Wilk W test (NCSS, 2001) was used to determine whether each parameter was normally distributed. Pearson's product moment correlations (NCSS, 2001) were used to determine the association between the parameters. Where a correlation was strong, linear regression analysis was performed to determine the nature of the relationship. The quantitative data for the 13 parameters were subjected to principal component analysis (PCA) (XLSTAT, 2011) to ascertain the number of linear combinations of optimally weighted variables that can explain the variability in the data set. The $\mathrm{CV}$ for various quantitative parameters was calculated as the SD between the means for the accessions divided by the general mean. An index of differentiation was calculated as the $\mathrm{CV}_{\text {between }}$ accessions $\mathrm{di}$ vided by the $\mathrm{CV}_{\text {within accessions. }}$.

\section{Results}

Color of the cut flower. Of the 82 accessions evaluated, the primary spathe colors of pink (20), red (16), and white (16) were the most common followed by obakes (14) (Fig. 1). The red, pink, and white accessions varied in the intensity of spathe pigmentation. Accessions with white spathes ranged from bright to pale white to white with pink veins and borders. There were red, pink, orange, coral, and white obake types with pink obake types being most abundant (five of 14). All the other spathe colors including orange and coral varied in number from two to six (Fig. 1). Regulatory patterning typified by green spathes with pink veins was observed in one of the green accessions.

The spadix colors of red accessions varied from straight yellow or straight pink to yellow-green, yellow-orange, yellow-red, purple-orange, and pink-yellow-green with yellow-green (seven accessions) being most common. There was considerably more variation in spadix colors among the pink (straight yellow, pink, red, and purple to combinations of yellow-green, yellow-red, pink-yellow, and pink-red) than in the red accessions. Typically, accessions with a white spathe had spadices that were yellow (eight of 16) followed in numbers by yellow-green (five of 16) and red/rose (three of 16). The spadix of accessions with green spathes always had green at the tip and sometimes even at the base, although pink, yellow, or orange colors also occurred at the base. Spadix colors of obake accessions showed considerable variation. The orange and coral accessions typically had yellow spadices except one coral accession that also had green coloration at the tip of the spadix. The two purple and two brown accessions had purple and brown spadices, respectively.

Peduncle colors were mainly green or maroon or a combination of the two. Where the two colors came together, the maroon was more pronounced on the upper end and green at the lower end. Green peduncles were slightly more abundant $(57 \%)$ than maroon or maroon-toned ones.

Spathe, spadix, and peduncle descriptors. Spathe length varied from $60 \mathrm{~mm}$ to $364 \mathrm{~mm}$ (mean, $167 \mathrm{~mm}$ ), whereas spathe width varied from $44 \mathrm{~mm}$ to $240 \mathrm{~mm}$ (mean, $116 \mathrm{~mm}$ ) (Table 1). The frequency distributions for spathe length (Fig. 2A) and spathe width (Fig. 2B) were skewed to the right. The frequency distribution for spathe size (spathe length $\times$ width) was sharply skewed to the right (Fig. 2C), indicating that most

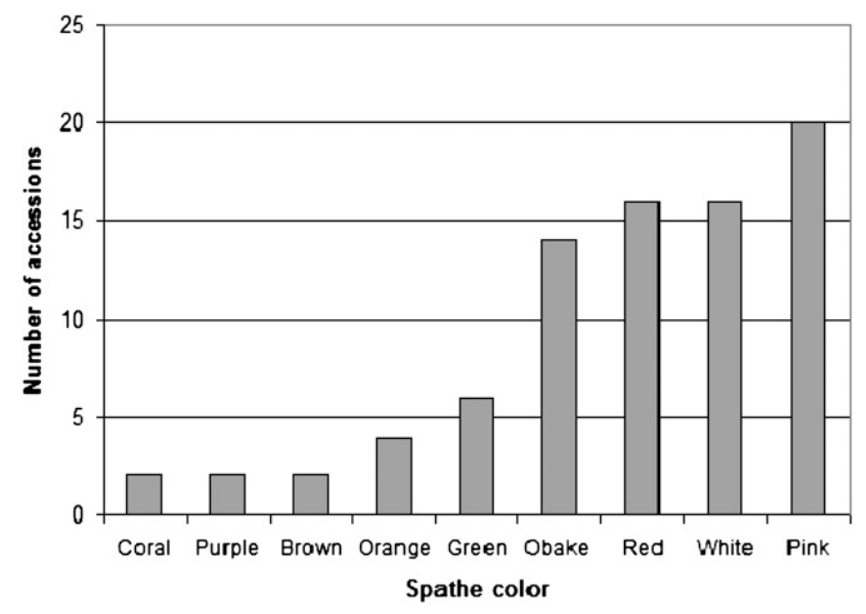

Fig. 1. Number of Anthurium andraeanum Hort. accessions found in each spathe color category grown in the Caribbean.

Table 1. The limits of variation, range, mean, and SE of 10 measured morphophysiological parameters of 82 Anthurium andraeanum Hort. accessions grown in the Caribbean.

\begin{tabular}{|c|c|c|c|c|c|c|c|c|}
\hline & Parameters & Limits & Range & Mean & $\begin{array}{l}\text { SE between } \\
\text { accessions }\end{array}$ & $\begin{array}{c}\mathrm{CV}(\%) \\
\text { between } \\
\text { accessions }\end{array}$ & $\begin{array}{c}\text { CV (\%) } \\
\text { within } \\
\text { accessions }\end{array}$ & $\mathrm{ID}^{2}$ \\
\hline \multirow[t]{7}{*}{$\overline{\text { Cut flower }}$} & Spathe length (mm) & $60-364$ & 304 & 167 & 65.2 & 39.1 & 5.7 & 6.9 \\
\hline & Spathe width (mm) & $44-240$ & 196 & 116 & 40.1 & 34.6 & 5.2 & 6.7 \\
\hline & Spadix length (mm) & $42-132$ & 90 & 71 & 15.8 & 22.3 & 3.6 & 6.2 \\
\hline & Spadix diameter $(\mathrm{mm})$ & $5-16$ & 11 & 10 & 1.8 & 18.3 & 4.6 & 4.0 \\
\hline & Spadix angle (deg.) & $22-83$ & 61 & 48 & 10.2 & 21.2 & 4.7 & 4.5 \\
\hline & Peduncle length (mm) & $246-849$ & 603 & 540 & 116 & 21.5 & 4.3 & 5.0 \\
\hline & Productivity & $4.5-10$ & 5.5 & 7 & 1.4 & 19.3 & 2.8 & 6.9 \\
\hline \multirow[t]{3}{*}{ Leaf } & Leaf length (mm) & $195-468$ & 273 & 337 & 64.7 & 19.2 & 4.0 & 4.8 \\
\hline & Leaf width (mm) & $120-310$ & 190 & 187 & 41.1 & 22.0 & 3.9 & 5.6 \\
\hline & Petiole length (mm) & $196-643$ & 447 & 403 & 106 & 26.2 & 5.2 & 5.0 \\
\hline
\end{tabular}

${ }^{\mathrm{z}}$ Index of differentiation. 
(a)

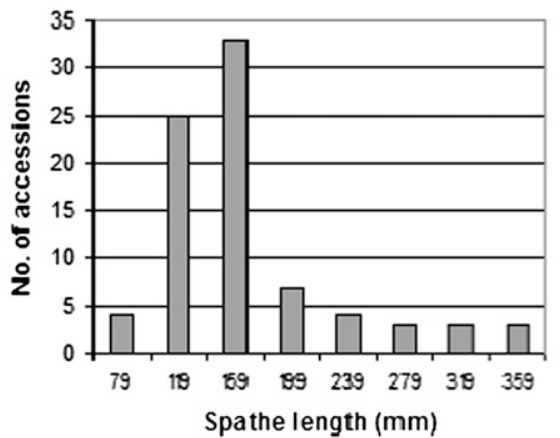

(c)

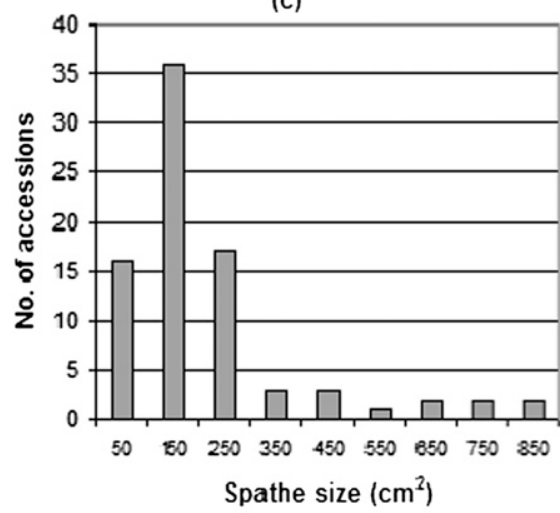

(e)

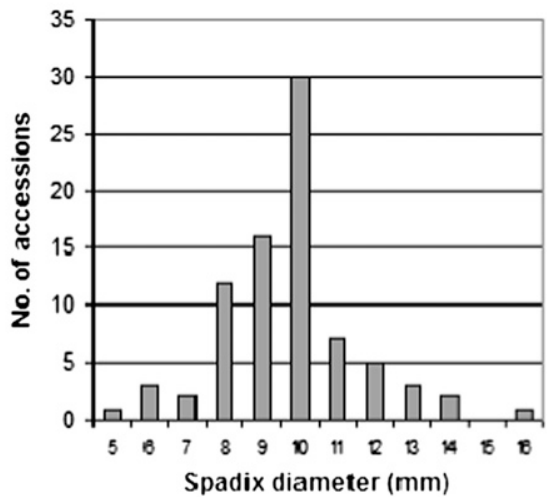

(b)

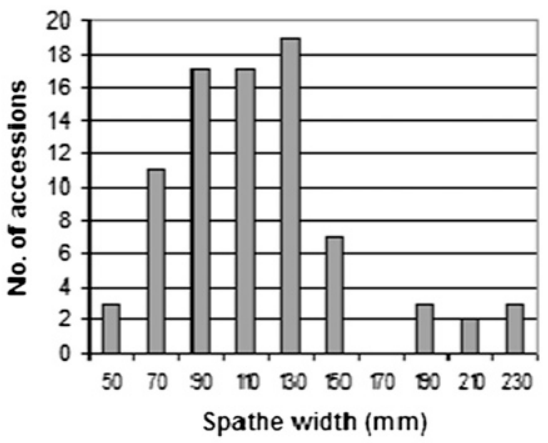

(d)

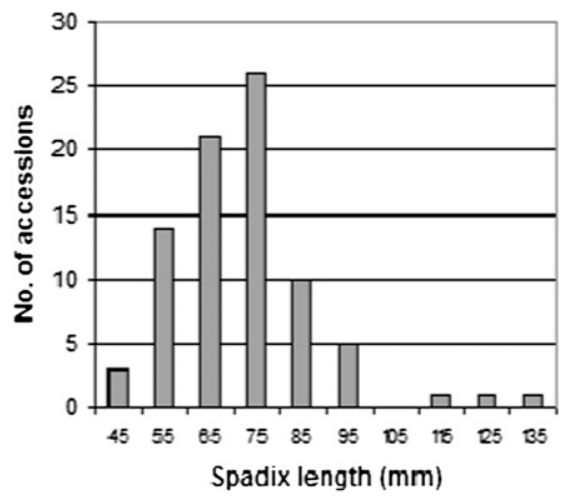

(f)

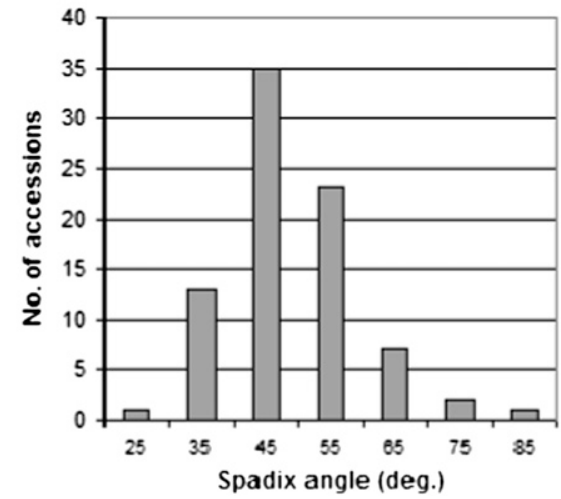

Fig. 2. (A-M) Frequency distributions for the 13 quantitative morphophysiological parameters measured in 82 Anthurium andraeanum Hort. accessions grown in the Caribbean.

accessions had smaller spathe sizes with only a small number possessing moderate and large spathe sizes.

Spadix length varied from $42 \mathrm{~mm}$ to $132 \mathrm{~mm}$, with a mean of $71 \mathrm{~mm}$, whereas spadix diameter varied from $5 \mathrm{~mm}$ to $16 \mathrm{~mm}$, with a mean of $10 \mathrm{~mm}$. The frequency distributions for spadix length (Fig. 2D) and spadix diameter (Fig. 2E) were skewed to the right. Spadix angle varied from $22^{\circ}$ to $83^{\circ}$ (mean, $48^{\circ}$ ) and was normally (Shapiro-Wilk W test probability $=0.059, P>0.05)$ distributed (Fig. 2F) with 41 accessions having spadix angles greater than $45^{\circ}$.

There was a 3.5 -fold variation among accessions for peduncle length (Table 1). The range for peduncle length was $603 \mathrm{~mm}$ (varying from $246 \mathrm{~mm}$ to $849 \mathrm{~mm}$; mean, $540 \mathrm{~mm}$ ) and the frequency distribution (Fig. 2G) was normal (Shapiro-Wilk $\mathrm{W}$ test probability $=$ $0.693, P>0.05)$.
Leaf descriptors. Leaf length varied from $195 \mathrm{~mm}$ to $468 \mathrm{~mm}$ (mean, $337 \mathrm{~mm}$ ). The smallest leaf width was $120 \mathrm{~mm}$, whereas the largest was $310 \mathrm{~mm}$; mean was $187 \mathrm{~mm}$. The frequency distribution for leaf length (Fig. 2H) was normal (Shapiro-Wilk W test probability $=0.487, P>0.05$ ), but that for leaf width was sharply skewed to the right (Fig. 2I).

Leaf size, estimated as the product of leaf length $\times$ width, showed a frequency distribution slightly skewed to the right, indicating that the smaller leaf sizes were more frequent than the larger sizes (Fig. 2J). Petiole length had a range of $447 \mathrm{~mm}$, varying from $196 \mathrm{~mm}$ to $643 \mathrm{~mm}$; mean was $403 \mathrm{~mm}$ (Table 1). The frequency distribution for petiole length (Fig. $2 \mathrm{~K}$ ) showed a normal distribution (ShapiroWilk W test probability $=0.551, P>0.05$ ).

Comparison of values indicates that peduncle length was always longer than petiole length except for three accessions, for which the reverse was true. Spathe showiness (difference between peduncle and petiole lengths) showed a distribution (Fig. 2L), which was normal (Shapiro-Wilk W test probability = 0.091, $P>0.05)$. Eighty-seven percent of all accessions had spathe showiness greater than $50 \mathrm{~mm}$.

Productivity. Productivity varied from 4.5 to 10 cut flowers per plant per year with a mean of 7.0 cut flowers per plant per year, respectively. The frequency distribution for productivity was sharply skewed to the right (Fig. 2M). Forty percent of accessions had higher than average productivity (greater than 7.0 cut flowers per plant per year), whereas $55 \%$ had productivity below the general mean of all accessions. Nineteen accessions $(23 \%)$ had productivity below 6.0 cut flowers per plant per year.

Spathe length and productivity had the highest index of differentiation (6.9), whereas spadix diameter had the lowest (4.0) (Table 1).

Correlation between parameters. Table 2 shows the correlation coefficients between various quantitative morphological parameters evaluated. Leaf length showed highly significant correlation $(r=0.30$ to $0.95 ; P<$ 0.01 to 0.001 ) with all parameters measured except spathe showiness, spadix angle, and productivity. The linear relationship between leaf length and width was strong: leaf length $(\mathrm{mm})=72.69+1.411$ leaf width $(\mathrm{mm}) ; \mathrm{SE}$ (slope) $=0.078 ; R^{2}=0.80$. Although there was a significant correlation between leaf length and petiole length $(r=0.73 ; P<$ 0.001 ), it was weaker than between leaf length and leaf width $(r=0.90 ; P<0.001)$. Leaf width also showed high correlation with petiole length $(r=0.77: P<0.001)$ and moderate correlation $(r=0.47$ to $0.59 ; P<$ 0.001 ) with peduncle length, spadix length, and spadix diameter. Petiole length also showed a strong correlation with peduncle length $(r=0.75 ; P<0.001)$.

Spathe length also showed a strong correlation $(P<0.01)$ with spathe width $(r=$ $0.91)$. The relationship between spathe length and width can be described by a linear regression equation: spathe length $(\mathrm{mm})=$ $-5.1981+1.4815$ spathe width $(\mathrm{mm})$; SE (slope) $=0.075 ; R^{2}=0.83$. Spadix length showed moderately strong correlation $(r=$ $0.54 ; P<0.01)$ with spadix diameter. Although the correlation between spathe length and leaf length was significant, it was moderate $(r=0.41 ; P<0.01)$. The correlation between spathe width and leaf width, however, was not significant.

Spathe showiness showed moderate but significant correlation $(P<0.001)$ with spathe length and spathe size $(r=0.48)$, spathe width $(r=0.53)$, and peduncle length $(r=0.46)$.

Principal component analysis. PCA showed that only the first three components displayed eigenvalues greater than 1 , and the results of a scree test (Cattell, 1966) also suggested that the first three components were meaningful (Fig. 3). Combined, principal components 1 and 2 and 1,2, and 3 
(g)

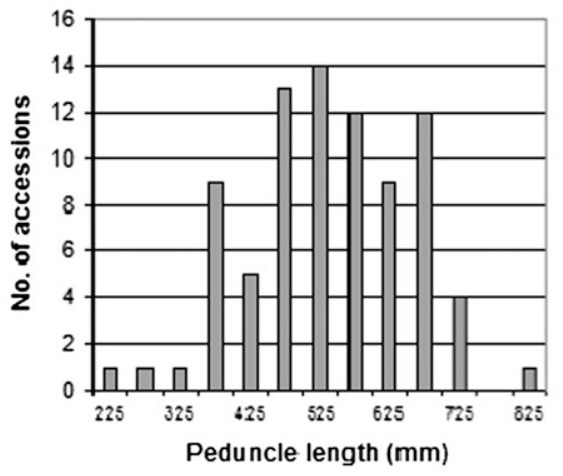

(i)

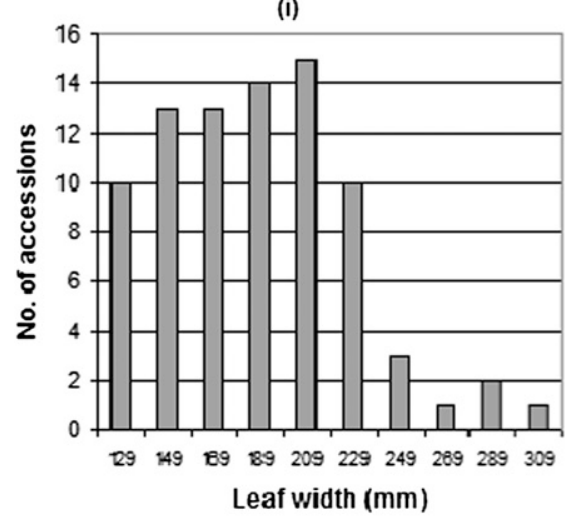

(k)

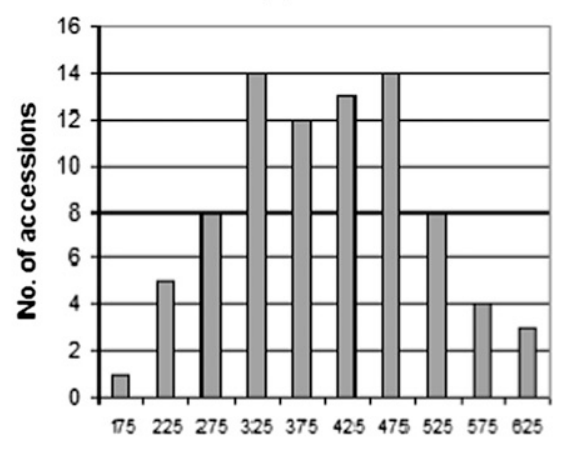

Petiole length $(\mathrm{mm})$

(m)

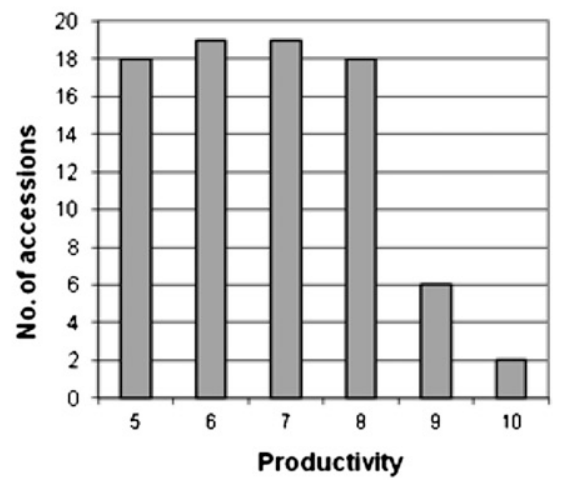

Fig. 2. (Continued)

accounted for $64.7 \%$ (Fig. 4) and $75.4 \%$ of the total variance (Fig. 3), respectively. Therefore, only the first three components were retained for varimax (orthogonal) rotation. In interpreting the rotated factor (h)

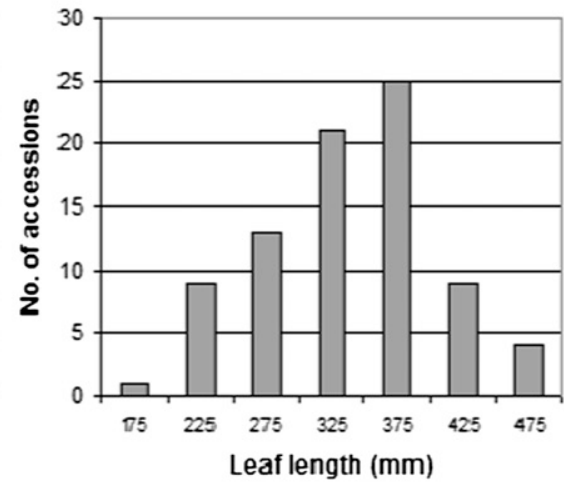

(j)

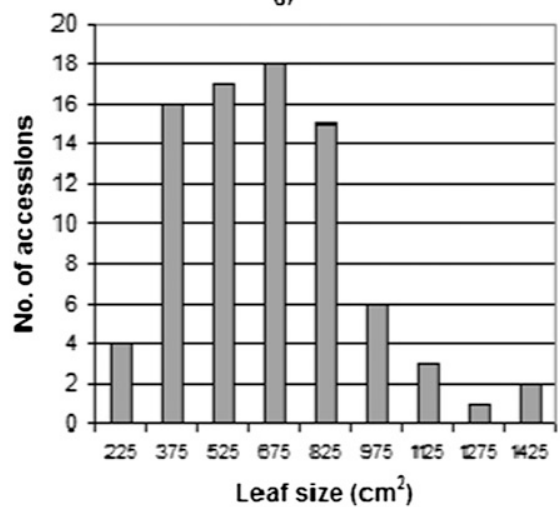

(I)

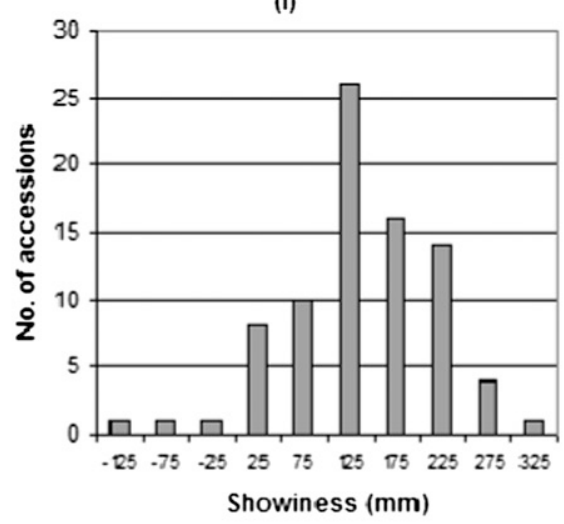

Showiness $(\mathrm{mm})$ pattern, an item was said to load to a given parameter if the factor loading was 0.4 or greater for that principal component and less that 0.4 for the other components. Using these criteria, three parameters were found to load on the first component viz. leaf length, leaf width, and leaf size; four parameters on the second component viz. spathe length, spathe width, spathe size, and spathe showiness; and two on the third component viz. peduncle length and productivity. The three parameters loaded on the first component can be referred to as leaf size parameters. The four parameters loaded on the second component can be referred to as spathe characteristics and the two parameters loaded on the third component can be referred to as productivity and acceptabilityrelated factors.

Based on the squared cosine table (Table 3 ) along with the three leaf size parameters, three others viz. petiole length, peduncle length, and spadix diameter loaded on the first component. The second component was loaded with the same three parameters as before, whereas the third component was loaded by only one item, productivity.

The study suggests that one of the leaf size parameters, one of the spathe size parameters, spathe showiness, petiole length, peduncle length, spadix diameter, and productivity as well as spathe, spadix, peduncle, and petiole colors can be used as descriptors for anthurium. Although spadix angle and spadix length did not load on the first three factors and were considered not important by PCA, because of their horticultural importance (market acceptability), they can be used as descriptors for anthurium.

\section{Discussion}

Anthurium accessions held at Kairi Blooms Farms is a collection established from farmers and hobbyists across the Caribbean, breeding lines selected at the farm as well as varieties imported from Hawaii, The Netherlands, and from other countries of Europe. It is not surprising that pink, red, white, and obake-spathed accessions were predominant in the collection, because this reflects the general trend for market appeal. In the Caribbean, red, white, and pink spathe colors are preferred for different occasions: weddings, anniversaries, funerals, birthdays, Christmas, Valentines' day, and Mother's day. In the North American market, there is a high demand for reds, whites, pinks, and obake types. In Hawaii (Halloran and Kuehnle, 1998) and Europe (van Herk et al., 1998), people prefer red anthurium cut flowers, especially the bright red ones, followed by pinks and whites, with orange being the least desired color. According to van Herk et al. (1998), in the 1980s, orange used to be the dominant spathe color in Europe, but its appeal has declined drastically in recent years. Although most of the anthurium accessions in the collection were standard types (possessing a single spathe color), bicolored (obake types) accessions and accessions with various regulatory patterns on the spathe were becoming increasingly popular in North American markets with a significant price premium.

Kamemoto and Kuehnle (1996) observed that red- and pink-spathed anthurium might have red to orange-red spadices of various 
Table 2. Pearson's product moment correlation coefficient between 13 morphophysiological parameters based on 82 accessions of Anthurium andraeanum Hort. grown in the Caribbean. ${ }^{z}$

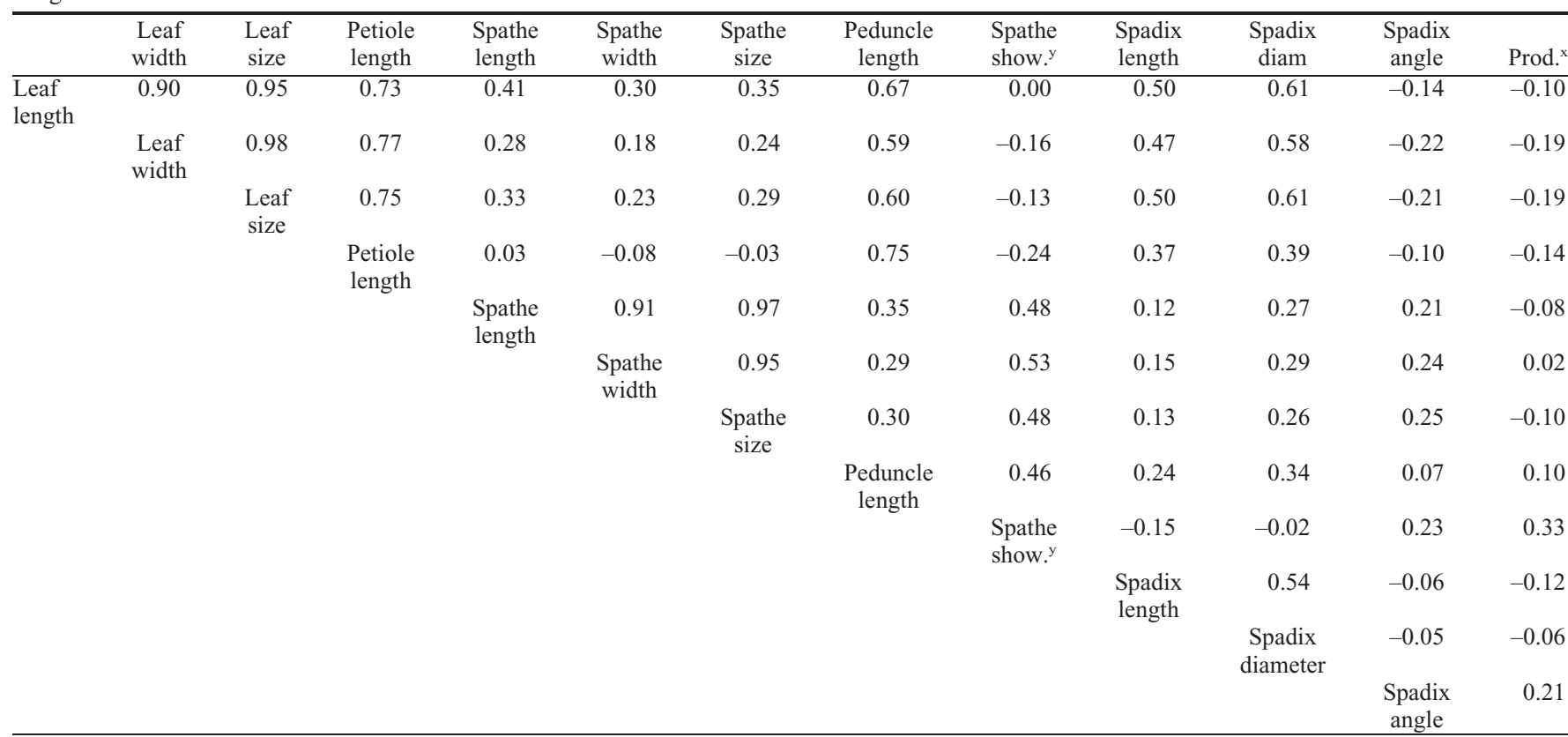

${ }^{\mathrm{z}}$ Correlation coefficients are significant at $P \leq 0.05$ and $P \leq 0.01$ at $80 \mathrm{df}$ when $r=0.217$ and 0.283 , respectively.

${ }^{\mathrm{y}}$ Show. $=$ showiness.

${ }^{\mathrm{x}}$ Prod. $=$ Productivity

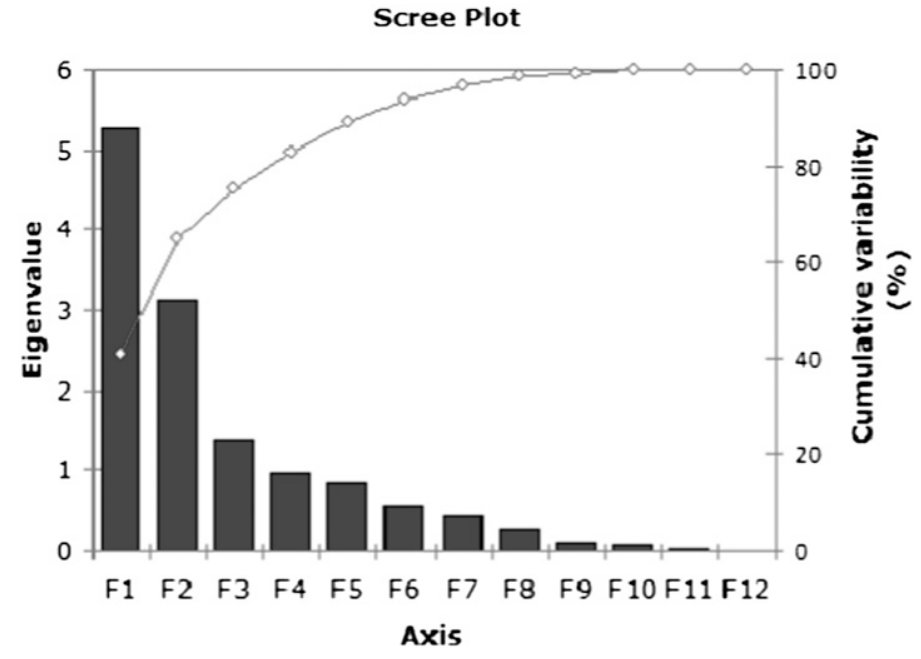

Fig. 3. Scree plot showing the eigenvalues and cumulative variability of the 12 components generated based on principal component analysis of the 13 quantitative variables measured for 82 accessions of Anthurium andraeanum Hort.

intensities in addition to those with a yellow spadix. However, anthurium accessions with red and pink spathe colors in the present study had a complete range of variation in spadix colors, indicating no correlation between spathe and spadix colors. Similarly, accessions with white spathes also showed a large variation in spadix colors. This larger range of spadix colors seen in the accessions perhaps reflects their complex origin through interspecific hybridization (Birdsey, 1951; Kamemoto and Kuehnle, 1996; Kamemoto and Nakasone, 1955, 1963) among anthurium species within the section, Calomystrium. The popular spadix colors for red and white spathe-colored accessions were yellow-green, whereas that for the pink-spathed accessions were shades of purple, pink, or sometimes red. This may reflect market preferences for these combinations rather than a correlation. The distinct genetic control of spathe (Elibox and Umaharan, 2008b) and spadix (Kamemoto and Kuehnle, 1996) colors proposed as well as the different pigments in spathe and spadix support the lack of correlation.

Internationally, spathe sizes are classified based on spathe width into seven categories (van Herk et al., 1998). Based on this classification, most of the accessions (57\%) studied fell into the medium or small spathe size categories with only $12 \%$ falling in the premium category. The distribution for spathe size was sharply skewed to the right (Fig. 2C). Sixtynine accessions $(84 \%)$ had spathe sizes less than $300 \mathrm{~cm}^{2}$, whereas only $9 \%$ of the accessions had spathe sizes greater than $500 \mathrm{~cm}^{2}$. In the markets, larger spathe sizes usually fetch higher prices for the cut flower, because larger spathes are showier than the smaller ones. However, spathes with a width greater than $152 \mathrm{~mm}$ do not fetch a premium on the market. The results show that there exists opportunity to improve the spathe size through breeding.

A spadix somewhat shorter than the length of the spathe and curved slightly downward is desirable for packaging and shipping cut flowers (Kamemoto and Kuehnle, 1996; Kamemoto et al., 1986). Only two (2\%) accessions in the collection possessed spadices whose lengths were larger than the spathe lengths; however, these two accessions are grown in very small numbers in the Caribbean. Kamemoto and Kuehnle (1996) reported that a spathe held at an angle of $45^{\circ}$ (spathe carriage) from the spadix is the most appealing and facilitates packaging. Fifty percent of the accessions possessed spadix angles larger than $45^{\circ}$; hence, there is great need for improvement in spadix angle in the anthuriums for market acceptability.

Peduncle length is an important horticultural parameter that determines the showiness of the cut flower in floral arrangements. A long, straight, and erect peduncle carrying the spathe well above the leaves is desirable (Kamemoto and Kuehnle, 1996). Long peduncles that hold the spathes at least $50 \mathrm{~mm}$ above the canopy are easier to harvest because these spathes are more visible and less prone to damage during harvesting. Peduncle length showed a wide variation with $\approx 90 \%$ 
Variables (axes F1 and F2: $64.72 \%$ )

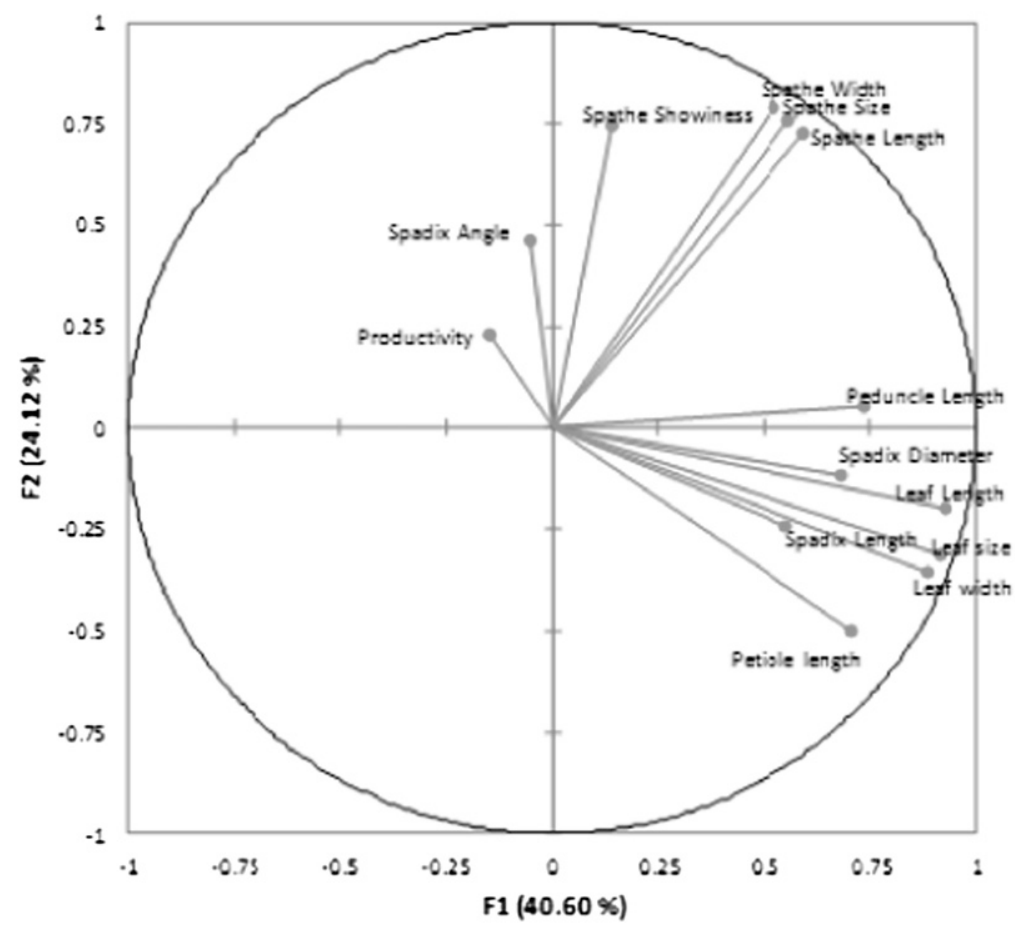

Fig. 4. The correlation circle on the F1 and F2 axes based on principal component analysis of the 13 quantitative variables measured for 82 accessions of Anthurium andraeanum Hort.

Table 3. Squared cosine table based on principal component analysis of each of the 13 quantitative parameters measured for 82 accessions of Anthurium andraeanum Hort. on the first three principal components.

\begin{tabular}{lccc}
\hline Parameter & F1 & F2 & F3 \\
\hline Leaf length & 0.863 & 0.039 & 0.004 \\
Leaf width & 0.780 & 0.127 & 0.000 \\
Leaf size & 0.836 & 0.099 & 0.001 \\
Petiole length & 0.500 & 0.249 & 0.084 \\
Spathe length & 0.354 & 0.525 & 0.055 \\
Spathe width & 0.270 & 0.622 & 0.045 \\
Spathe size & 0.313 & 0.579 & 0.076 \\
Peduncle length & 0.547 & 0.003 & 0.305 \\
Spathe showiness & 0.020 & 0.555 & 0.180 \\
Spadix length & 0.303 & 0.060 & 0.031 \\
Spadix diameter & 0.468 & 0.014 & 0.011 \\
Spadix angle & 0.002 & 0.213 & 0.075 \\
Productivity & 0.021 & 0.051 & 0.520 \\
\hline
\end{tabular}

of the accessions possessing peduncle lengths between $350 \mathrm{~mm}$ and $700 \mathrm{~mm}$ (Fig. 2G).

Spathe showiness, defined as the difference between peduncle and petiole length, showed a distribution that was normal (Fig. $2 \mathrm{~L}$ ) with $87 \%$ of the accessions exceeding the standard of $50 \mathrm{~mm}$. Besides facilitating harvesting, a showy inflorescence well above the leaf canopy may be an adaptation for crosspollination (Chouteau et al., 2008) by insects and birds, and hence this character may also be under natural selection.

Anthurium leaves are popularly used as decorative greenery in floral arrangements and have a well-developed market (van Herk et al., 1998). Furthermore, the market for anthurium leaves has grown in recent years and continues to do so. Well-formed, glossy leaves are preferred (van Herk et al., 1998). Categorization of leaf size in international markets has been reported by van Herk et al. (1998), and based on it, 32\% of the accessions fell below the small leaf category (leaf width of 200 to $249 \mathrm{~mm}$ ) and hence cannot be marketed internationally. van Herk et al. (1998) indicated that the older leaves of anthurium, which tend to be large, are unproductive as a result of mutual shading by the younger leaves, and expend much sugar that could otherwise go toward cut-flower production. Furthermore, too many leaves and especially too many large leaves suppress flower emergence, increase flower abortion, cause damage to flowers, and lead to crooked peduncles (van Herk et al., 1998). Moreover, accessions with larger leaves have to be planted further apart to prevent overlapping of leaves. Accessions with larger leaves therefore require leaf pruning (van Herk et al., 1998) to ensure greater flower production and larger flowers. Leaf pruning is also beneficial because it enhances air circulation thereby suppressing mould and bacterial infections (van Herk et al., 1998).

Leaf length was always larger than leaf width in all accessions. It is advantageous to have longer and narrower leaves held around the stem to effectively harness light for photosynthesis. Based on the phyllotaxy of anthurium (Dufour and Guerin, 2003), it seems that longer petioles would prevent crowding of leaves around the stem, thus improving light interception. As inflorescences develop in the axils of leaves, it follows that the greater the number of leaves, the greater would be the number of inflorescences produced.
Anthuriums are grown primarily for cut flowers. Cut-flower production, therefore, is the most important selection criterion in anthurium breeding (van Herk et al., 1998). On average, a single growing anthurium plant produces only five to six cut flowers per year, so a difference of one cut flower per plant per year may translate into large economic differences (Kamemoto and Kuehnle, 1996). Because cut flowers develop in each leaf axil during the sympodial phase of growth (Dai and Paull, 1990; Dufour and Guerin, 2003; Higaki et al., 1994), the more vigorous an accession is, the more productive it would be. The mean productivity overall the accessions was 7.0 cut flowers per plant per year, which was just about the average level of six to seven set by commercial farmers worldwide. Furthermore, some of the most productive accessions also combine other good horticultural features such as leaf length and width; spathe length and width; peduncle length; and spadix length and angle. Such features would be ideal characteristics of parents chosen for breeding programs.

There was a strong and positive correlation between leaf length and width $(0.90)$ as well as between spathe length and width (0.91), which suggested that any one of the two measurements could be used to determine leaf and spathe size. The results conform to international standards that use spathe width as a measure of spathe size (van Herk et al., 1998). Although the correlation between leaf size and spathe size was highly significant $(P<$ $0.01)$, the $r$ value $(0.29)$ was small. Hence, the linear association between these two parameters was very weak. This argues well for breeding because larger spathe size with a smaller leaf size is preferred in a horticultural ideotype of anthurium.

There was also a strong correlation between petiole and peduncle length $(r=0.75)$. Spathe showiness had a moderately strong correlation with peduncle length $(r=0.46)$ but only a weak correlation $(P<0.05)$ with petiole length $(r=-0.24)$. This suggests that direct selection for showiness will be more effective than selecting for peduncle length or petiole length.

Productivity in this study was not significantly correlated to any other horticultural parameter studied and hence could be independently improved without affecting other horticultural parameters. PCA also showed that productivity was loaded independently on the third component. Productivity seems to be affected primarily by the rate of leaf production (Dai and Paull, 1990; Klapwijk and van der Spek, 1988) and, therefore, the vigor. Because vigor is influenced to a large extent by environment, environmental adaptability must be important to ensure high productivity. As anthurium evolved as an understory species in tropical forests (Croat, 1988; Henny et al., 1991), fewer leaves with larger leaf sizes may have been an adaptive feature.

In conclusion, this study shows horticulturally important parameters that are useful as descriptors of Anthurium andraeanum Hort. Character correlations show that productivity 
can be improved without adversely affecting other horticultural attributes, which are important for horticultural improvement of anthurium. An anthurium ideotype for cut-flower production should be vigorous, producing a large number of narrow, small leaves held on long, erect petioles. The cut flowers should be held high above the leaves on long peduncles with glossy heart-shaped (symmetrical) spathes with a spadix (proportional to the size of the spathe) held at an angle less than $45^{\circ}$.

\section{Literature Cited}

Birdsey, M.R. 1951. The cultivated aroids. The Gillick Press, Berkeley, CA.

Cattell, R.B. 1966. The scree test for the number of factors. Multivariate Behav. Res. 1:245-276.

Chouteau, M., M. Gibernau, and D. Barabé. 2008. Relationships between floral characters, pollination mechanisms, life forms, and habitats in Araceae. Bot. J. Linn. Soc. 156:29-42.

Croat, T.B. 1988. Ecology and life forms of Araceae. Aroideana 11:4-55.

Dai, J. and R.E. Paull. 1990. The role of leaf development on anthurium flower growth. J. Amer. Soc. Hort. Sci. 115:901-905.
Dilbar, A. 1992. Studies on a new bacterial disease and other diseases of anthurium in Trinidad. MSc diss., Univ. West Indies, St. Augustine, Trinidad.

Dufour, L. and V. Guerin. 2003. Growth, developmental features and flower production of $\mathrm{An}$ thurium andraeanum Lind. Sci. Hort. 98:25-35.

Elibox, W. and P. Umaharan. 2008a. Morphophysiological characteristics associated with vase-life of cut flowers of Anthurium. HortScience 43:825-831.

Elibox, W. and P. Umaharan. 2008b. Inheritance of major spathe colors in Anthurium andraeanum Hort. is determined by three major genes. HortScience 43:787-791.

Halloran, J.M. and A.R. Kuehnle. 1998. What do anthurium buyers want in their flowers? Results of a market survey. Univ. of Hawaii, CTAHR Coop. Ext. Ser. EFS 27.

Henny, R.J., A.R. Chase, and L.S. Osborne. 1991. Anthurium production guide. Apopka Fol. Plant Res. Note RH-91-3.

Higaki, T., J.S. Lichty, and D. Moniz. 1994 Anthurium culture in Hawaii. HITAHR Res. Ext. Ser. 152.

Kamemoto, H. and A.R. Kuehnle. 1996. Breeding anthuriums in Hawaii. Univ. Hawaii Press, Honolulu, HI.
Kamemoto, H., J. Kunisaki, M. Aragaki, and T. Higaki. 1986. Evaluation of anthurium accessions. HITAHR Res. Ext. Ser. 069

Kamemoto, H. and H.Y. Nakasone. 1955. Improving anthuriums through breeding. Hawaii Farm Sci. 3:4-5.

Kamemoto, H. and H.Y. Nakasone. 1963. Evaluation and improvement of anthurium clones. Hawaii Agr. Exp. Sta. Tech. Bull. 58.

Klapwijk, D. and H.J.H. van der Spek. 1988 Development rate, flower growth and production of anthurium. Neth. J. Agr. Sci. 36:219224.

NCSS. 2001. Number Crunching Statistical System. NCSS, Kaysville, UT.

Rapsey, J.A.D. and T.W.A. Carr. 1968. Anthurium growing in Trinidad and Tobago. Proc. Trop. Reg. Amer. Soc. Hort. Sci. 12:274-283.

Rosario, T.L. 1981. Varietal evaluation of $A n-$ thurium andraeanum Lind. Phil. Agr. 64:191196.

van Herk, I.M., I.M. van Koppen, I.S. Smeding, I.C. van der Elzen, N. van Rosmalen, I.J. van Dijk, I.A. Lont, and I.J. van Spingelen. 1998. Cultivation guide Anthurium. Anthura, Bleiswijk, The Netherlands.

XLSTAT. 2011. XLSTAT. Addinsoft, New York, NY. 